\title{
INVESTIGATION ON CALORIC TEST IN RABBITS
}

By

\section{H. INO, AND I. TAKEYAMA}

\section{From the Department of Oto-Rhino-Laryngology, the 2nd. Tokyo National Hospital}

Authors aimed to confirm the adequate method of caloric test in rabbits and then investigated on the conditions of test, that is position of head, the temperature and quantity of water for irrigation, the time of irrigation and test interval.

The results obtained were summarized as follows:

1) We made clear from the anatomical study of skull in rabbits that horizontal semicircular canal is located on the line darwn through the upper part of bony external meatus and the lateral part of the supraorbital margin.

Therefore we fixed the head of rabbit horizontally to the plane including the attached part of external auditory meatus and the lateral part of the upper eye-lid, in which the horizontal semicircular canal lies horizontally.

And then we declined the fixed-apparatus backward about $40 \sim 50 \%$. This is the most adequate position for induction of caloric reaction in rabbits.

2) Speaking on the temperature and quantity of water for irrigation $10^{\circ} \mathrm{C} 10 \mathrm{cc}$ for cold stimulation and $55^{\circ} \mathrm{C} 20 \mathrm{cc}$ for hot stimulation, is considered to be adequate.

We recommend at these conditions to irrigate for 5 seconds in one, 10 seconds in another towards the upper wall of external meatus.

3) It is advisable to have at least 15 minutes interval between first test and next one.

4) On the judgment of results, it is important to consider right-left difference of duration of nystagmus rather than the length of duration.

And if the right-left difference of duration is more than 10 minutes. it will be reasonable that the results of test were considered as abnormal.

\section{家鬼におけるCaloric Testの検討}

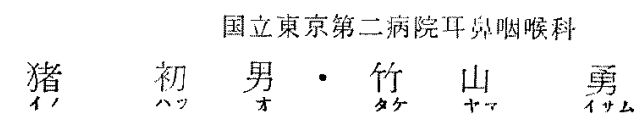

\section{緒言}

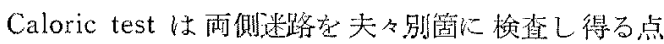

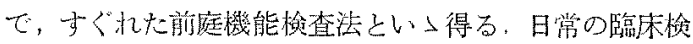
查法としての calorc test については既に Hallplke ${ }^{5)}$, Jongkees ${ }^{13)}$ ，㒂 ${ }^{10)}$ 等の馀絸な研究発表があるが動物寒 睁における外耳道注水による caloric test については

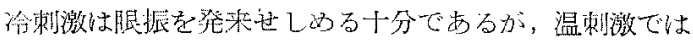
眼拢の篟来が不明暸であるとされ，現在のところ動物を

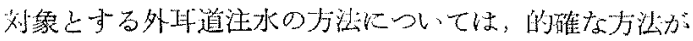

見当らない現情である。

我ふは家象における適止な caloric testを見い出与 ことを目的として，磌位，注水温，注水量，注水時間， 注水間隔等について検討を加えた。

\section{研 究方 法}

成熟家鬼（約 $2 \mathrm{~kg}$ ) て鼓膜, 外耳道に異常なく, 自発 脏振，頭位腿振を認めないるのを使朋し，ヂめ $10^{\circ} \mathrm{C}$

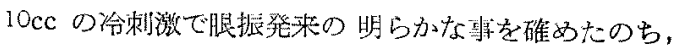

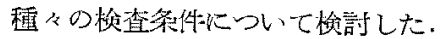


1. 頭 位

動物を種々の頭位におき，备頭位における腿振反応を 観察した。

先づ最初に, 注水により腿振の発来しない位置, 即ら Indifferent position を求め, 次にこの頭位を基点とし 頭を後届 $30^{\circ}, 60^{\circ}, 90^{\circ}$ と次第に後届せしめ, 各頭位に 拈ける潜伏時間, 眼振数, 腿振持続時間を測定した（第 1 表).

第 1 表 各頭位に扣ける潜伏時間，順振数， 持続時間

\begin{tabular}{|c|c|c|c|c|}
\hline 頭 & 位 & 潜伏時間 & 眼振数 & 持続時間 \\
\hline Indifferent & position & $\phi$ & $\phi$ & $\phi$ \\
\hline 传 到 & $30^{\circ}$ & 7 秒 & 16 & 37 杪 \\
\hline$"$ & arjo & 4 & 118 & 64 \\
\hline " & 4 & 2 & 131 & 58 \\
\hline
\end{tabular}

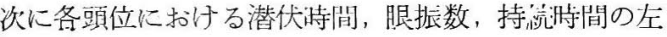
右差について娭討すると次表の如くなる（第2表）.

第 2 表 各頭位に和ける潜伏時間, 顺振数, 持続時間の左右差

\begin{tabular}{cc|c|c|c}
\hline 頭 & 位 & 潜伏時間 & 眼振数 & 持続時間 \\
\hline \hline 後 出 $30^{\circ}$ & 6 秒 & 7 & 13 秒 \\
" $60^{\circ}$ & 3 & 22 & 7 \\
" & $90^{\circ}$ & 2 & 53 & 11
\end{tabular}

以上の成績から頭を後屈せしめるに従い，潜伏時間は 減少し，眼振数，眼振持続時間は增加することが分る. 一方これを眼振左右差からみると, 後屈 $60^{\circ}$ の頭位で眼 振持続時間の左右差が最も少いことが分る.

次に家鬼の水平半規管の位置を調へ，この位置を基点 として頭位を工夫してみた，家鬼の水平半規管の位置は 写真 1 に示才如く, 外耳道上端之眼窩外縁上端を結ぶ線 にほべ平行しており，これが水平面に対する角度は平均 34〜400である(写真 1 ).

従つて水平半規管を中心にして考觉ると，家鬼を腹位 で固定した場合の水平半規管は水平面に対し上記角度だ け前傾した位置にあることになる，そこで普通の固定位 置（腹位）から Indifferent positionを沃める場合， 上記解剖的関係を考慮し，耳翼附着部と上腿瞼外縁とを 結ぶ線が 水平林る位置で動物を固定する必要がある (写真 2).

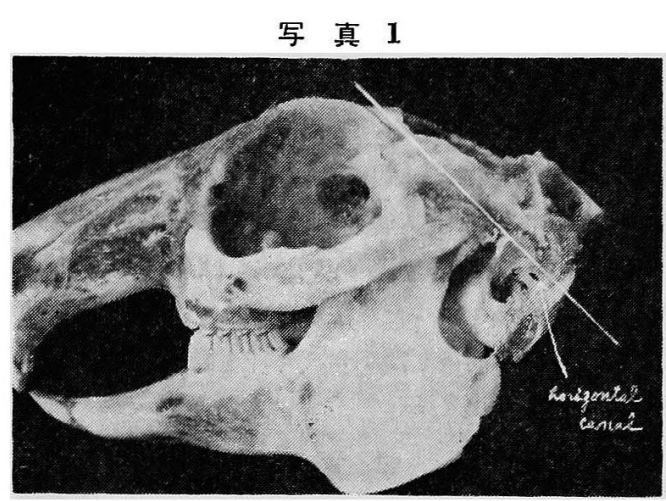

写 真 2

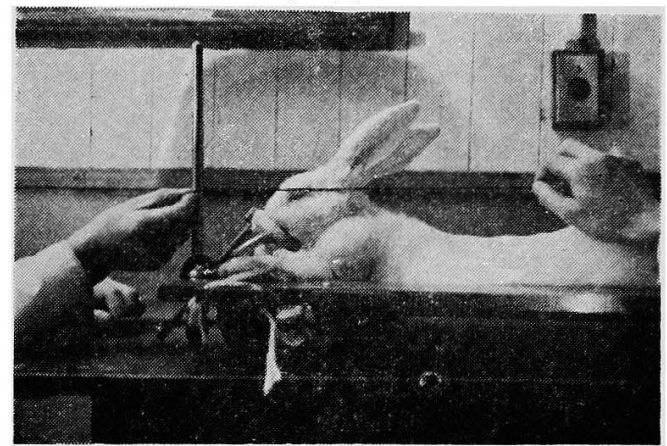

この位置では注水しても眼振が起きないから適度に頭 を後屈し, 半規管の傾きを增加せしめる必要がある。

Indifferent position から $30^{\circ}$ 後屈せしぬた頭位は他 の頭位に比し, 眼振数, 持続時間共に小さい 従つて更 に後屈度を增加せしめるため固定台を 40〜500傾けた位 置で注水を試みた。この位置での潜伏時間, 眼振数, 眼 振持続時間及び夫ヶの眼振左右差を第 3 表に示寸

第 3 表 後屈 40〜 50॰ 頭位における潜伏時間， 艮振数，持続時間及び左右差

\begin{tabular}{|c|c|c|c|}
\hline & 潜伏洔間 & 惟振数 & 持続時間 \\
\hline 後屈 $40 \sim 50^{\circ}$ & 4秒 & 106 & 62秒 \\
\hline 左 右 差 & 1.3 & 17 & 5 \\
\hline
\end{tabular}

この值は前述した後屈 $60^{\circ}$ の值とほડ゙等しいが腿振左 右差は更に小さい，またこの位置で固定するときは注水 に際して動物は騒暴とならず，比䡥的安定した状態で注 水し得る，且つこの固定位置では腿球偏位も認められな いので腿振の钼察も容易で,この頙位は家兔における注 水頙位として適当なものと考えられる。 
2. 注水条件（注水温, 注水量, 注水時問)

上記の至適頭位にして备種注水条件について検諯し た. 注水温は $10^{\circ} \mathrm{C} か 555^{\circ} \mathrm{C}$ までの温度を用い, 注 水量は $10 \mathrm{cc}$ から $60 \mathrm{cc}$ とし, $20 \mathrm{cc}$ 屯では $20 \mathrm{cc}$ 注射简 の先にネラトンのコム管をつけ，更に开管カテーテル

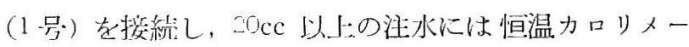
ターを川小注水を行つた。注水に際しては, 耳鏡を川い 区射鏡で鼓膜を明視しふがら，外耳道後上壁に向つて泣:

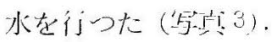

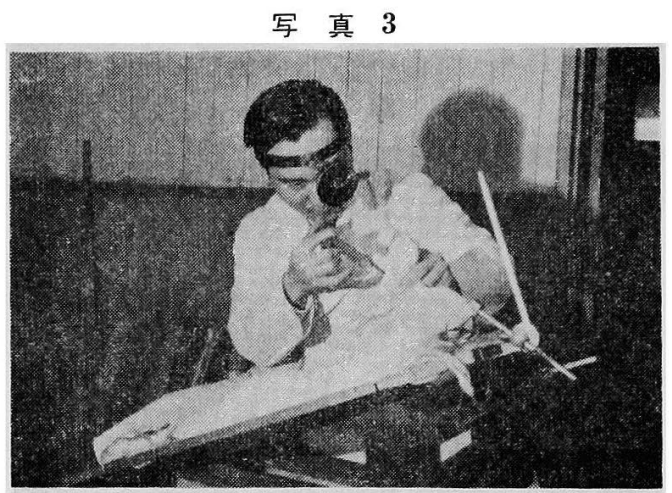

家鬼 10 羽 20 耳を対象とし, 注水温を $10^{\circ} \mathrm{C}, 20^{\circ} \mathrm{C}$, $30^{\circ} \mathrm{C}, 44^{\circ} \mathrm{C}, 50^{\circ} \mathrm{C}, 55^{\circ} \mathrm{C}$, 注水量を $10 \mathrm{cc}, 20 \mathrm{cc}, 40 \mathrm{cc}$, $60 \mathrm{cc}$ として夫々 5 秒, 10 秒, 20 秒, 30 秒の注水時間で 注水した成續を一括して第 4 表に示与

第 4 表 各種注水条件と温度性㙄振の発現莩

\begin{tabular}{|c|c|c|c|c|c|c|}
\hline \multirow{2}{*}{ 注 水量 } & \multicolumn{2}{|r|}{ 注 } & \multicolumn{2}{|c|}{ 水 } & \multicolumn{2}{|l|}{ 温 } \\
\hline & $10 \mathrm{C}$ & $20^{\circ} \mathrm{C}$ & $30 \mathrm{C}$ & $44^{\circ} \mathrm{C}$ & $50 \mathrm{C}$ & $55 \mathrm{C}$ \\
\hline $10 c c$ & $20 / 20$ & $20 / 20$ & $0 / 20$ & $0 / 20$ & $11 / 20$ & $20 / 20$ \\
\hline $20 c c$ & $20 / 20$ & $20 / 20$ & $7 / 20$ & $5 / 20$ & $13 / 20$ & $20 / 20$ \\
\hline $40 \mathrm{cc}$ & $20 / 20$ & $20 / 20$ & $9 / 20$ & $7 / 20$ & $16 / 20$ & $20 / 20$ \\
\hline $60 \mathrm{cc}$ & $20 / 20$ & $20 / 20$ & $11 / 20$ & $10 / 20$ & $17 / 20$ & $20 / 20$ \\
\hline
\end{tabular}

この成續は上記注水条件の注水により眼振を発来した

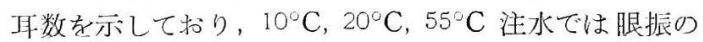
発現を全例に恐めるが， $30^{\circ} \mathrm{C}, 44^{\circ} \mathrm{C}$ 注水ではその約半 数に眼振を認めたに過ぎない, 注水量からみると, $10 \mathrm{cc}$ 注水では $10^{\circ} \mathrm{C}, 20^{\circ} \mathrm{C}, 55^{\circ} \mathrm{C}$ の注水温に対し全例に腿振 の発現を認めたが $50^{\circ} \mathrm{C}$ では約半数に, $30^{\circ} \mathrm{C}, 44^{\circ} \mathrm{C}$ で は全例に眼振を認めないことになる。20 cc に対しては $30^{\circ} \mathrm{C}, 44 \mathrm{C}, 50 \mathrm{C}$ の注水温の場合, 夫々 20 例叶7 例, 5 例, 13 例に腿振を認め, $60 \mathrm{cc}$ では夫々 20 例中 11 例,
10 例, 17 例に眼振の 発現をみており, 注水量を㘿加す ると腿振発現率は增加寸るが， $30^{\circ} \mathrm{C}, 44^{\circ} \mathrm{C}$ では全例に 眼振の発現をみる訳にはいかない。

次に $20 \mathrm{cc}$ 注水の際の备注水温度における潜伏時間, 眼振持続洔閪を示すと第 5 表の吙くなる。

第 5 表 行砫㳔水温 ( $20 \mathrm{cc}$ 泟水) と

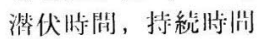

\begin{tabular}{|c|c|c|}
\hline 注: 水 温 & 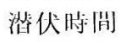 & 持総㫾㨔 \\
\hline $10^{\circ} \mathrm{C}$ & 2秒 & 83秒 \\
\hline $20^{\circ} \mathrm{C}$ & 4 & 45 \\
\hline $30^{\circ} \mathrm{C}$ & 7 & 23 \\
\hline $44^{\circ} \mathrm{C}$ & 9 & 17 \\
\hline $50^{\circ} \mathrm{C}$ & 6 & 29 \\
\hline $5.5 \mathrm{C}$ & 3 & 42 \\
\hline
\end{tabular}

このことから 2000 注水で適当な腿张持続时間を得る には，10-C，20 C，55Cが望ましいと考えられる。

そこで $10^{\circ} \mathrm{C}(10 \mathrm{cc}), 20^{\circ} \mathrm{C}(20 \mathrm{cc}), 55^{\circ} \mathrm{C}(20 \mathrm{cc})$ の注

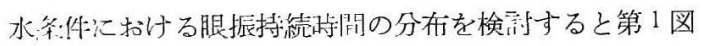
の如くなる.

第 1 図各注水条件に水ける眼振持続時間の分们

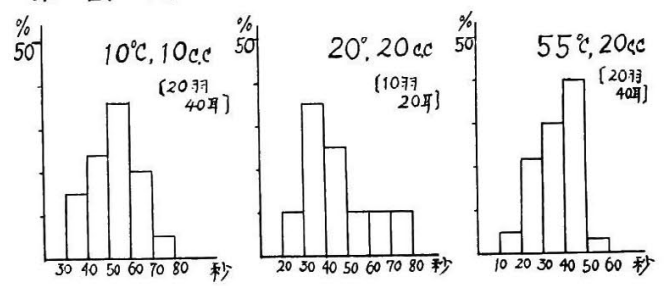

この図から分るように $10^{\circ} \mathrm{C}, 10 \mathrm{cc}$ 注水では全例の $62.5 \%$ が 40〜60 秒の持続時間を示し, $20^{\circ} \mathrm{C}, 20 \mathrm{cc}$ では 全例の 60\% が 30 50 秒， $55 \circ \mathrm{C} ， 20 \mathrm{cc}$ では全例の $70 \%$ が 30〜50秒の持続時間を示して括る.

次に各々の眼振持続時間の左右差の分布をみると第 2 図の如くなる。

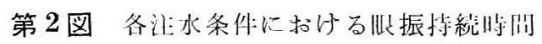
左右差の分们

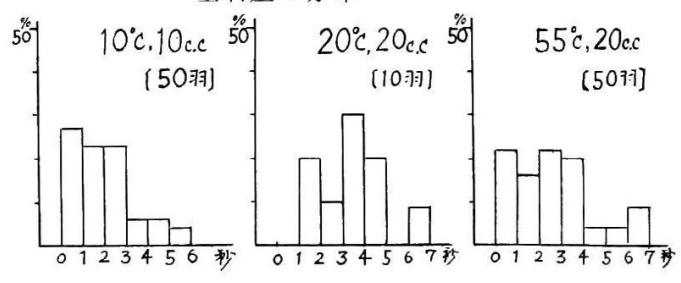




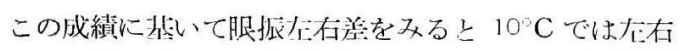

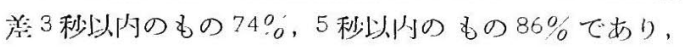
$200 \mathrm{C}$ では 5 秒以内のもの $80^{\circ}$ 。, $55 \mathrm{C}$ では 5 秒以内 のもの $84 \%$ とい5結果を示しており，特拓 $10 \%$, $55^{\circ} \mathrm{C}$ では実に $85 \%$ 内外が左右差 5 秒以队にとがまつて いる.

また $10^{\circ} \mathrm{C}(10 \mathrm{cc}), 20^{\circ} \mathrm{C}(20 \mathrm{cc}), 55^{\circ} \mathrm{C}(20 \mathrm{cc})$ 注水 による腿振持続時間を統計学们に検討した成績を第 6 表 に示す

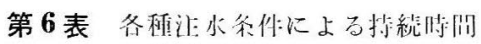

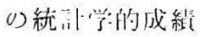

\begin{tabular}{|c|c|c|c|c|c|c|}
\hline & \multicolumn{2}{|c|}{$10 \mathrm{C}, 10 \mathrm{cc}$} & \multicolumn{2}{|c|}{$20^{\circ} \mathrm{C}, 20 \mathrm{cc}$} & \multicolumn{2}{|c|}{$55^{\circ} \mathrm{C}, 20 \mathrm{cc}$} \\
\hline & 左耳. & 在四。 & 左压 & 份仃。 & 应可. & 有叮. \\
\hline 平妁 值 & 58.9 & 58.8 & 45.3 & 44.8 & 42.2 & 42.1 \\
\hline 標準偏差 & 9.52 & 9.52 & 14.55 & 12.35 & 11.16 & 11.61 \\
\hline 信頼限界 & 2.7 & 2.7 & 10.84 & 9.18 & 4.1 & 4.3 \\
\hline 臙却限界 & 19.61 & 19.04 & 36.43 & 30.88 & 22.76 & 23.63 \\
\hline
\end{tabular}

これらの成績から命刺激としては $20^{\circ} \mathrm{C}(20 \mathrm{cc})$ より $10^{\circ} \mathrm{C}(10 \mathrm{cc})$ の汃遥かにすぐれて扣り，温刺激として は $55^{\circ} \mathrm{C}(20 \mathrm{cc})$ が寺ぐれた条件と考党られる。

またこれら両者による腿振持続時間の左右差がいう も極めて小さい事は温度性腿振検查法の注水条件として この両者が最も適当なことを锥書きしている。

3. 検査間隔

次に同一家克につき $10^{\circ} \mathrm{C}, 10 \mathrm{cc} 5$ 秒注水の注水条作 で10分标きに，注水し眼振持続時間の推移を観察した。

この場合の成績は第 3 図に示寸如く，眼振持続時間の 減少は認められない。

第 3 図 $10^{\circ} \mathrm{C}, 10 \mathrm{cc} 5$ 秒注水（10分おき）に よる持続洔閆の推移

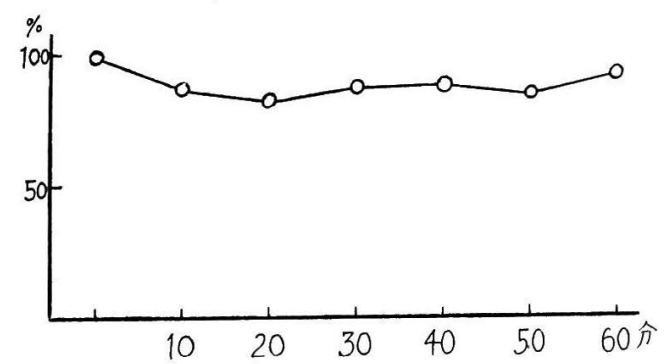

一淮に廻転検査では刺激を反覆して与古ると反応の減 弱, 即ち Response decline (R.D) 現象がみられるが caloric test でけか〉る見象は起らないといら8)。この

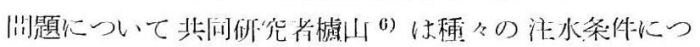

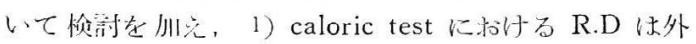
耳道に由米しないこと，2）一侧冷，他僛温の闬侧间川寺: 注水に上る反雉刺激では著明な R.D を認めることを確 認し, 家乘の caloric test では注水条州により R.D の 起り得ることを明らかにした。

次に初回注水後の外耳道, 迷路の温度变化を头験的に 計測し，検查閌隔についての検討を行つた。

この結果, 外耳道に対する温度效果が完全に去るまで にも〜ア分を要し，迷路の温度变化が完全に消失するま てには 13〜14 分を要することが判明した。從つて初川 注水の影缲が完金に去つてから次回注水を行う事が望ま

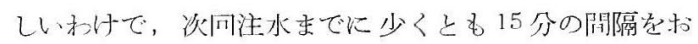
くことが毞ましことが分つた。

\section{1. 顥位について: \\ 考按}

Caloric nystagmus の本態に関し, Barany2) は温度変 化により半規管内に内リンパの浾れが起るといら説, 即 ち内リンパ流動説を発表したが，彼はまた caloric test における腿振の方向は水温のみならず頭位によつても变 り得ることを明らかにし，発来せる腿振の方向は半規管 の位置に関係すると述べている、また Borries ${ }^{3)}$ は耳石 系にその主役を求め, caloric nystagmus が頭位に依存 することは主として耳石の影響に基つくものであるとい ら見解を述べて扣る．近年に至り Jongkees ${ }^{14)}$ は caloric respone は耳石系を含む全迷路の反応，特に水平 半規管の㡰応であると述べておる. Kristensen ${ }^{18)}$ は海 埧及び家蚛について caloric test を行い，その際の頭 位の檢語を試みておる.海埧の側頭骨の解剖学的研究か ら，水平半規管の位置は外耳道下端と眼简下縁を結ぶ

写 真 4

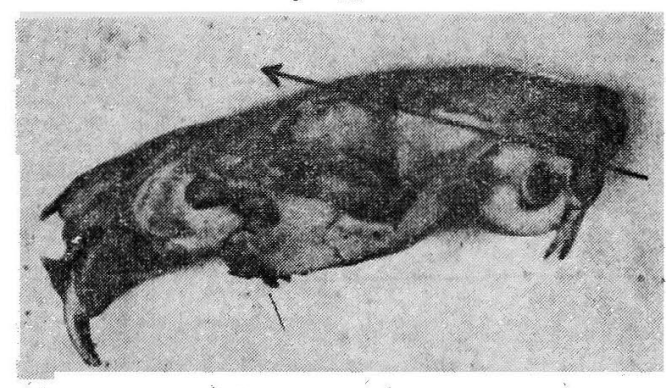

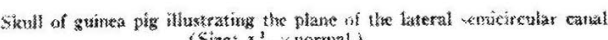
(Size: $x^{3}, \times$ normal.) 


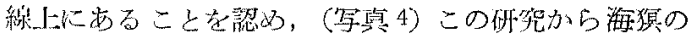

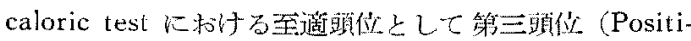
on 3 : lying on the back with elevated head) 提唱 して掠子 (写真 5$)$.

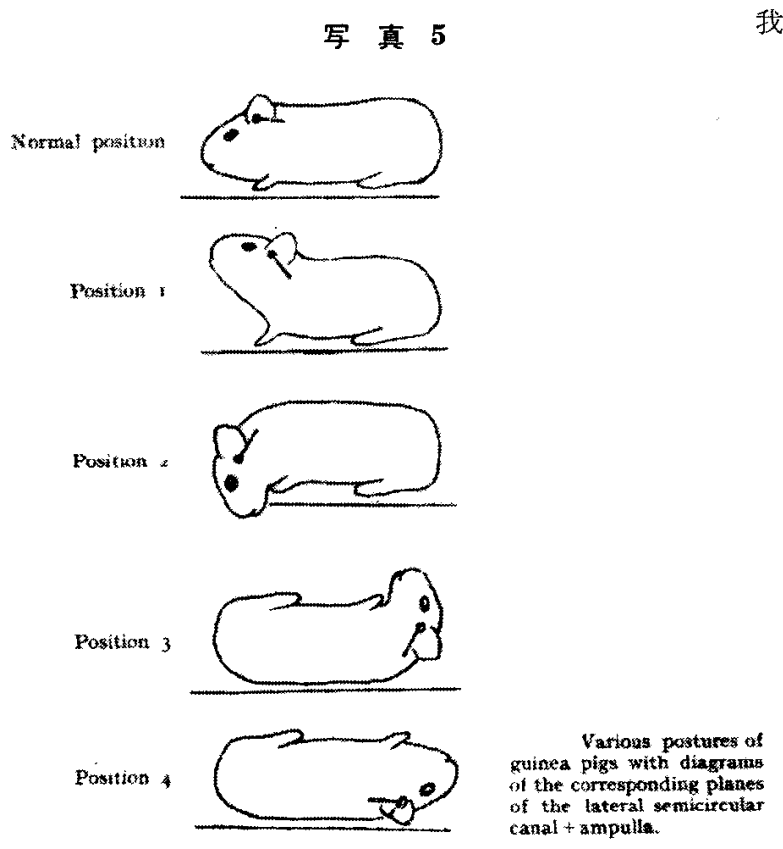

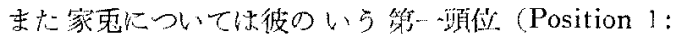

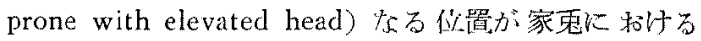
caloric reaction の発現に灼して至適䁰位であると迅心 て扰る(写真 6).

我々は家束について同様の観祭を試みたところ，家冤 の水平半規管は外耳道上端之眼简外縁上端を結ふ 綠上にある事を確め，この位置は水平面に対し 340〜400の角度をなして扔ることを明らか以し t.

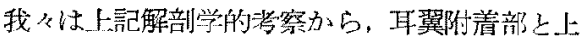
眼脸外緑を結心゙線が固定台水平面と平行になる上 らにして Indifferent positionをきめ，その後固

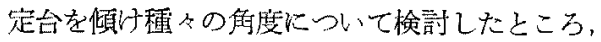

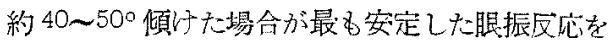
示すことが分つた。

頭位の後屈度を墙加させると，一般に潜伏時閆 は短かくなり持続時間は延長する。しかし该屈度 を強く一ると注水中に眼振の発現がみられ，潜伏 時間を湘定することが困難となるから，あまり後 屈度の強い頭位をとることは好ましくない

また頭の媛屈度を大きく寸ると，動物は不安 定となり暴れ几，注水当円滑に行い得ない事西る し，また腿球偏位をきたし眼振の観察に困難を伴 〔つたり，また注水せる水が直りに落下して適当な 温度刘果を与充ないともあるから，頭位の後屈には自 ら限界があることに在西，良つて後屈 $60^{\circ}$ の頍位上り後 屈度がゆるく且つ後屈 $30^{\circ}$ の磌位に和けるよりはつきり した眼振反応を観察できる頭位が望ましいこれらの条 件を考慮し，後屈 $30^{\circ}$ 及び $60^{\circ}$ の頭位已前述の至適頙位 に扣ける成績とを比較すると，後屆 300 の晹合は潜伏时 闒 7 秒，眼振数 16 ，持続時間 37 秒，後屈 600 の境合は 潜伏時聞 4 秒，眼振数 118 ，持続洔間 64 秒であるが， 前述の至谪頭位では潜伏時間 4 秒，眼振数 106，持涜眭 間 62 秒で後屈 $60^{\circ}$ の頭位と注心゙等しく, 且つ潜伏時間, 持続時間共に 40 500 後屈の至適頍位が最も左右差が小 さいことが分る，従つてこの頭位が家象の場合最も適当 な嗔位とい省る。

2. 注水温, 注水量について:

動物の caloric testでは一般に令溂激では腿振をよく

Varion powstares at rakbats vith fiagratros of the entresporating phanes of thel atersi ampalla

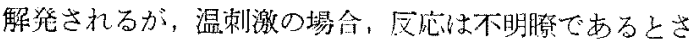
れている。

Jongkees ${ }^{14)}$ 俚注水温度を整端火但下せしめると却っ 


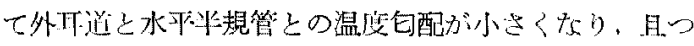

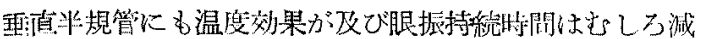

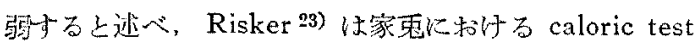
の際化 $10^{\circ} \mathrm{C}$ 以下の注水ては㗨为 homolateral nystag-

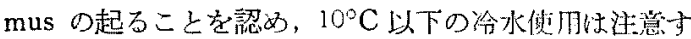
べきであり. $20^{\circ} \mathrm{C}, 50 \mathrm{cc}$ が適当な注水条件で就万うと 述べている.

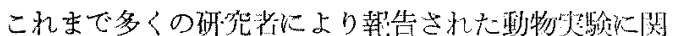
寸る注水忞件のいくつかを列記すると第 7 㤗の如くであ る.
が佥刺湤の服界とい总る

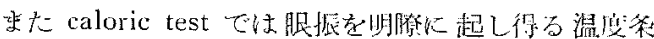

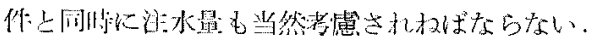

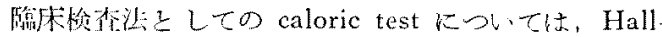
pike 4) 5) を代裴とする大量注水江：Kobrak 15) 代表上

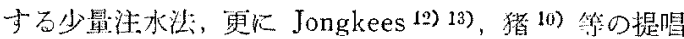

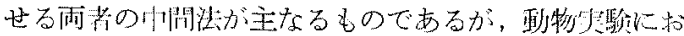

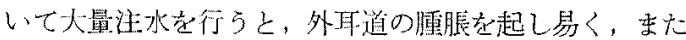
動物が期弱することも屡々であるので，少量注水が望生

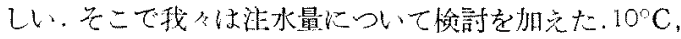
$20^{\circ} \mathrm{C}$ の注水温の場命, $10 \mathrm{cc}$ の注水量でむ明膫な眼振民 応を認めるが，眼振持続時 間の左右差について比較す る上， $20^{\circ} \mathrm{C}$ では左右差が 大き， との分布度子広箶

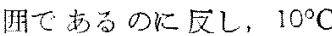
では左右差加非常に小さ W.

このことから $10^{\circ} \mathrm{C}$ がす ぐれているとい党る。

李た $55^{\circ} \mathrm{C}$ の場合は，20cc を注水することに上つて腿 振の発現む著明であり眼振 左右差电栖めて小さいこと が分った

このことから家束に执け る注水条件として, 冷刺激 には $10^{\circ} \mathrm{C} 10 \mathrm{cc} 5$ 秒注水,

我々は先ず注水温を検討するため，家乘体温（平均 $38^{\circ} \mathrm{C}$ 前徭）から等しい温度美の冷・温を採用したい々 洘光, 最初 $\pm 18^{\circ} \mathrm{C}$, 即古 $20^{\circ} \mathrm{C} と 56^{\circ} \mathrm{C}$ (実駼には $55^{\circ} \mathrm{C}$ 使用）について観察した。この両者は共に腿振度応怯明 膫活潑であり，特汇 $55^{\circ} \mathrm{C}$ では著明な眼振の発来老不 た. 次似 $10^{\circ} \mathrm{C}, 20^{\circ} \mathrm{C}, 30^{\circ} \mathrm{C}, 44^{\circ} \mathrm{C}, 50^{\circ} \mathrm{C}, 55^{\circ} \mathrm{C}$ \%条温

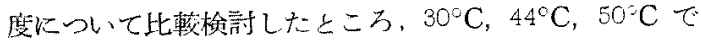
《眼振が不明膫か，発現しない事むあり，特洼注水量が $20 \mathrm{cc}$ 以下の場命は腿振発現率が著しく低下する。1 $10^{\circ} \mathrm{C}$ ， $20^{\circ} \mathrm{C}, 55^{\circ} \mathrm{C}, 20 \mathrm{cc}$ 注水では $100 \%$ の腿振発現䜌である が, $55^{\circ} \mathrm{C}$ の湯合 $10 \mathrm{cc}$ 注水では $20 \mathrm{cc}$ の注水量に比し 眼振名遥加微弱となるすのが多い。

以上の事から $10^{\circ} \mathrm{C}, 20^{\circ} \mathrm{C}, 55^{\circ} \mathrm{C}$ が注水温として適当 な温度であり，また諸家の成積を䝧考し家虫ては $10^{\circ} \mathrm{C}$
温刺激には $55^{\circ} \mathrm{C} 20 \mathrm{cc} 10$ 秒注水がもつともすぐれてい るといるる

3. 検植閒隔について

Caloric test K批いて温度刺湤を加光る埸合, 初回注

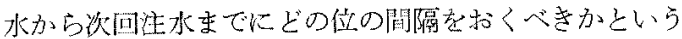
ことも考鳌を払わ杖ばなら間題である。この点につ き，我々は注水による外耳道，迷路に及致与专温度効果を

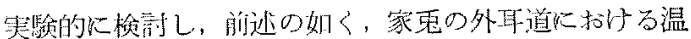
度効果仕，注水温と休温との差が+17〜 - $30^{\circ} \mathrm{C}$ の埸命，

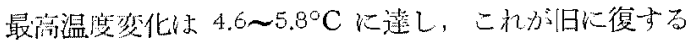
までの㭙間は6分20秒９分20秒であことが分の た。 また迷路に怙ける温度効果は，注水温々の美が $+19^{\circ} \mathrm{C} \sim-26^{\circ} \mathrm{C}$ 範团では最高温度变化は $0.95 \sim 1.0^{\circ} \mathrm{C}$ 


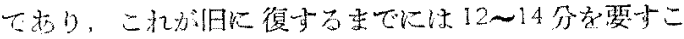
と分分った，これらの成緥から考察寸る上，初回注水に 上る外耳道及び迷路の温度药化か完全に去つてから炏回 の注水を行うべきで，家范で以少々とも15 分の注水閌 隔を挌くべきで西方ら。

4. 潜伏時間, 眼振数，持続時間について：

上迠した注水条件で caloric test 行い，潜俣時間， 眼非数, 持続侍間について觀察を行つた，頭位の後屈度 が增加与るに伴い，また注水温，注水量の変化化伴い，

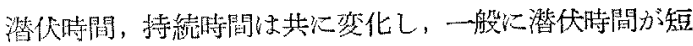

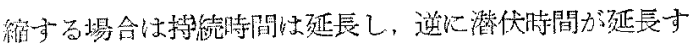
る場台は持続時間分短縮している。

咲来 caloric test の検盉成鼣を判定する場合，潜伏時

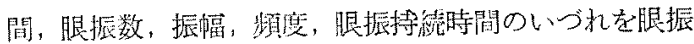
反応の Indicator とするかについて種々椧議されてお

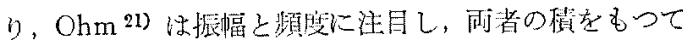
前庭反応の土ネルギーであるとし，Mittermaier ${ }^{19)}$ は振 幅と覑度を重視してその総和でる Gesamtamplitude (総振幅值)が持続時間上りも一層忠実《前庭原応のエネ ルギーを表現するものであると述べて招る．Henrikss-

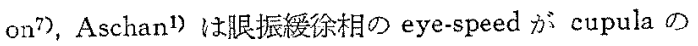
㾫倚以一致与ることを確認し, 前庭反心のエネルギー計 算にこの eye-speed を追加して扣り，また Henriksson 小池 ${ }^{16) 172}$ 等は電気的微分回路を利用し eye-speed の 直接記録见成功し，眼振緩除相の eye-speed こそ迷路 区応の判定に大い《役立っこと強張して坫古。朴沢 ${ }^{9}$ は潜伏時間は側頭骨の解剖的条件见左右されるものであ るから，午の意議は少いとし，持続時間を重要視してい

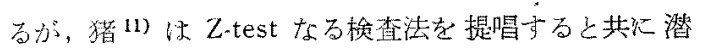

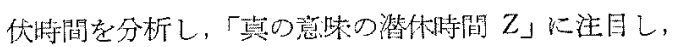
潜伏時閒の意義を過少棓価してはならぬと力説してお。 ๖.

我々の実駼成紸からみても，潜伏封間は頭位の变化に

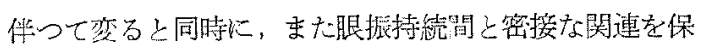
つていることがわかる。このことから潜伏時間もまた捨

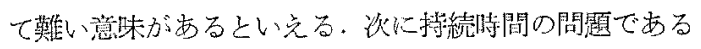
が，彷来は持綕時間の長短をもつて Hypernystagmus Hyponystagmus と判断する傾向が支配的であつたが，

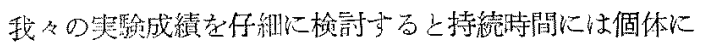
よりかなりの幅があることが分つた。この东は温度性

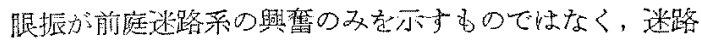
外因了 (extralabyrinthine factor) によつても影響さ れるためであるう、特次 caloric test では外耳道和覚,

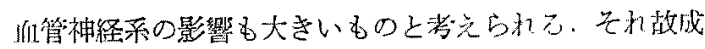
績判定にあたつては眼振持続侍間の辰短てはなく，至し

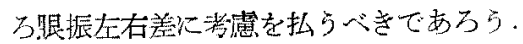

前莛機能検查に際しこの腿振左右差 (Vestibular asymmetry）の有無を確認することが㮌好重要なこと を重初て強調したい、森本 ${ }^{50}$ ) は左右迷路機能のアンバ ランスが高度の場合は自発眼振となり，軽度の場合は眼 振左右美として現れると述いて招り，岡本 ${ }^{22)}$ (臨床例 に怙ける caloric testでメニエール氏病に和ける左右差

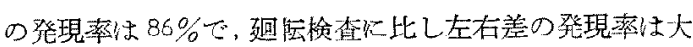
きい之述べている. Hallpike 4) 5) は左右差200。 以上の 場合を黑常と見做し，眼振持続時間の長短ではなく，腿 振方向を中心にして眼振の左右比較を行い.Directional preponderance (D.P) 及び Canal paresis (C.P) 极る 概念を caloric test の判定に導入した。

我々もできるたけ左右差の少ない注水桑件を選定する

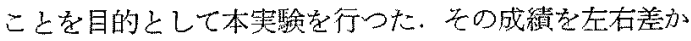
ら两ると左右差 5 秒以内のものは $10^{\circ} \mathrm{C} 10 \mathrm{cc} 5$ 秒注水 で法 $86 \%, 55^{\circ} \mathrm{C} 20 \mathrm{cc} 10$ 秒注水で $84 \%$ となり，その 差が極文て㙫少である事を確認した。

従ってかかる注水条件で10 秒以上の左右善を有する 場合には一忙異常とみなして差えないものと考克られ る.

\section{結論}

家臣について外耳道注水による caloric test の検查条 件を検討し次の如き結論を得た。

1) 頭位は最初耳翼附着部上上服瞼外縁を結ら゙線が水 平になる位置で固定し, 关の後固定台を 40〜50傾けた 位置で注水するのが最も適当である。

2) 注水温, 注水量についてい光ば领刺激上して $10^{\circ} \mathrm{C}$ $10 \mathrm{cc}$, 温刺激としては $55^{\circ} \mathrm{C} 20 \mathrm{cc}$ を夫 5 秒，10 秒の 注水㭙阙で外耳道後上壁儿向って注水することが望至し (.

3) 次回注水亲での注水間隔は15 分の間隔を戈くく事が 望ましい。

4)成續判定にあたつては腿振持続侍間の長短よりも

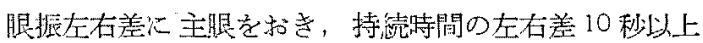
のときは一応異归定すべきであるう。

\section{参考文 献}

1) Aschan, G.: The mechanism of the cupula ampullaris in man. Acta Soc. Med. Upusala, $77: 3 \sim 4$, 1955. 2) Barany, R.: Untersuchungen über den vom Vestibularapparat des Ohres refektorisch aus. 
gelösten rhythmischen Nystagmus und seine Begleiterscheinungen. Mschr. f. Ohrenh. 40: 193, 1906. 3) Borries, G.V. Th.: Theorie des kalorischen $\mathrm{Ny}$. stagmus. Arch. Ohren-usw. Heilk. 113: 117, 1925. 4) Hallpike, C.S.: The caloric test. J, Laryng \& Otolog. 70: 1956. 5) Cawthorne, T.E., Fitzgerald, C. \& Hallpike, C.S.: Studies in buman vestebular function: a. Observation on the directional preponderance "Nystagmusbereitschaft" of caloric nystagmus resultiug from cerebral leision. Brain $65: 115$, 1942. b. Observation on the directional preponderance of caloric nystagmus ("Nystagmusbereitschaft") resulting from unilateral labyrinthectomy. Brain 65 : 138, 1942. 6) 跕山夕光: Caloric response decline

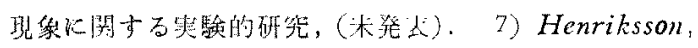
N.G.: An electrical method for registration and analysis of the movement of the eye in nystagmus. Acta Otolaryng. 45: 25, 1955. The corrclation between the speed of the eye in the slow phase of $n y$. stagmus and vestibular stimulus. Acta Otolaryng. 45: 120, 1955. 8) Hood, J.D., Pfaltz, C.R.: Observation upon the effects of repeated stimulation upon rotational aud caloric nystagmus. J. Physiol. 124: 130,1954.9）朴沢二即：逃路機能娭盗の再椮 尉, 日夲舆, 59:7 䀡31. 10) 猫初男: Caloric test

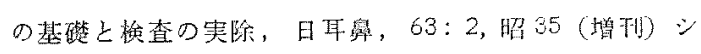

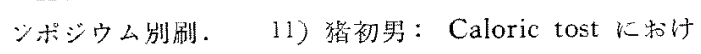

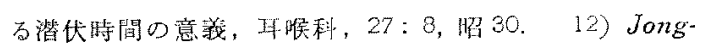
kees, L.B.W.: Value of the caloric test of the labyrinth. Arch. Otolaryng. 48: 402, 1948 . 13) Jongkees, L.B.W.: Which is the preferable method of performing the caloric test? Arch Otolaryng. 49:
594, 1949. 14) Jongkees, L.B.W: Origin of the caloric reaction of the labyrinth. Arch. Otolaryng. 48: 645, 1948. 15) Kobrak, F.; Beiträge zum experimentellen Nystagmus. Beitr, z. Anat, Physiol., Path. u. Therap. d. Ohres. 10:214, 1918; 11:244, 1919. Contributions to functional pathology of the ear. Principles of sensivility snd efficiency of the ear. J. Laryng. \& Otolog. 59: 171, 1941. 16) 小纯

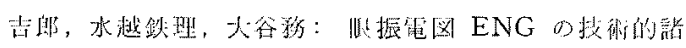

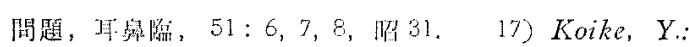
An observation on the eye-speed ot nystagmus. Acta Otolaryng. 50: 377, 1959 . 18) Kristensen, H.K.: Caloric reactions in guinea pig and rabbit. Acta otol. aryng. $44: 126,1954$. 19) Millermaier, R. 4. Chr. istian, W.: Dauer, Schlagzahl und Gesamtamplitude des kalorischen Nystagmus. Zschr. f. L.R.O. $53: 20$,

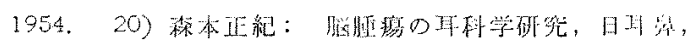
$58: 1374$, 炤 30 (得題垠告). 21) Ohm, J.: Frequ enz und Bahn des Augenzitterns der Bergleute in langer Beobachtung. Grafes Arch. Ophth. 141:604,

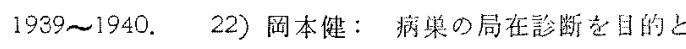

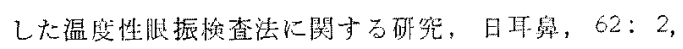
昭 $34 . \quad 23)$ Risker, N. \& Permin, P.: Homolateral nystagmus in rabbits on caloric test. Acta Otolary. ng. $44: 61,1954$,

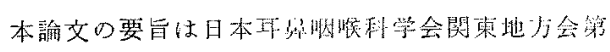

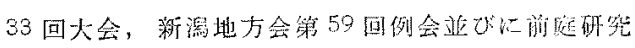
会の箱いに执いてロ湼した。

（原税到着二昭和 36.3 .10 日） 